\title{
The Influence of "Internet Plus" and Regional Culture: Basic Concept and Judgment Indicators
}

\author{
Weiling Jiang \\ School of Communication \\ Huaiyin Normal University \\ Huaian, China 223300
}

\begin{abstract}
Regional culture is a reflection of regional economic and political levels. It carries the profound heritage inherited from various historical periods. It has integrated various cultural features from ancient to modern times and from the inside out, forming a comprehensive cultural body. Now under the background of the "Internet Plus" program which has penetrated into various industries in various regions of the country, how to scientifically determine regional cultural influence is particularly necessary. This paper mainly proposes regional cultural influence indicators in the context of "Internet Plus" from historical accumulation, modern development and mass impressions.
\end{abstract}

Keywords-“Internet Plus"; regional culture; cultural influence; judgment indicators

\section{INTRODUCTION}

On November 14, 2012, Edward Yu, chairman and CEO of Analysis International, put forward the concept of "Internet Plus" for the first time at the Fifth Mobile Internet Expo. In his view, the so-called "Internet Plus" is the penetration and change of the Internet to traditional industries. In the future, products and services of all walks of life can use the characteristics of the Internet for promotion and development. In March 2015, Ma Huateng submitted the Proposal on Promoting the Development of China's Economic and Social Innovation with the "Internet Plus" as the Driving Force at the two sessions and suggested to insist on "Internet Plus" as the development drive to advance China's economy. In the Government Work Report of the 3rd Session of the 12th National People's Congress, Premier Li Keqiang also pointed out clearly that "the 'Internet Plus' action plan shall be formulated to promote the integration of mobile internet, cloud computing, big data and internet of things with modern manufacturing, boost the healthy development of e-commerce, industrial Internet and Internet finance and guide Internet companies to expand the international market."[1] Since then, the "Internet Plus" program has officially entered the public's field of vision as a national strategy, pointing the way for future development of various fields in China.

\section{BASIC CONCEPT}

\section{A. "Internet Plus"}

"Internet Plus" refers to the in-depth integration of "the Internet's innovation results with various sectors of the economy and society, promoting technological advancement, efficiency improvement and organizational reform, enhancing the innovation and productivity of the real economy and forming a new type of economic and social development broadly based on Internet as the infrastructure and innovation elements."[2]. At the same time, "Internet Plus" also specifically refers to the combination of the Internet and traditional industries, using Internet technologies to create relationships between traditional industries that have no relationship, through the use of high-tech means such as cloud computing and big data to complete the exchange of information between industries and integrate with the real economy. "MyBus" relies on the Internet to track and update the geographical location and number of vehicles in real time, reduce users' waiting time and avoid delays. "DiDi" provides real-time updates and delivery of taxis and user locations, which not only facilitates user's trip, but also solves the problem of supply and demand imbalances in the taxi industry, besides the combination of the Internet and the medical industry can effectively improve the imbalance in the allocation of medical resources. All this shows that using the "Internet Plus" can bring advantages to all walks of life. "Internet Plus" also means "to export superior functions to other traditional industries through the Internet, so that the advantages of the Internet can be applied to every aspect of traditional industry production, marketing and business activities"[3]. Therefore, the traditional industries need to use the advantages of the Internet to explore their own advantages and achieve online and offline synchronization and integration instead of treating is as a single communication tool

The purpose of "Internet Plus" is to complete the traditional industrial upgrading and economic restructuring. Compared with traditional industries, "plus" in the "Internet Plus" is the adjustment of its own industrial model. Through adjustments, the industry can gain insight into the direction of product and market development and provide users with personalized services. The Internet will certainly further promote the expansion of the product market in the development and production of traditional industrial products. "Internet Plus" 
utilizes its own characteristics of sharing and openness, which not only enables the traditional industry market and scale to achieve cross-regional development, but also brings new resources to traditional industries in the process of product production.

\section{B. Regional Cultural Influence}

Culture is formed in the long-term production and creation of mankind and reflects the historical development and social changes of mankind. Water and soil of one region give birth to a specific culture in that region, which in turn affects the development of the regional economy. The mutual influence of historical culture, traditional customs and geographical environment determines the different production modes in different regions. As it is with a country, the different regional cultures formed in each region further form a national culture. In different regions, the difference of politics, economy, and environment continues to evolve and interact under the long river of history, which directly or indirectly formed the different languages, religious beliefs, living habits, personality traits and moral concepts of residents in each region. Therefore, the regional culture is formed by different political and economic conditions due to different historical backgrounds in different regions and further produces different cultural values and customs. Regional culture can be divided into economic culture, political culture and spiritual civilization. Economic culture refers to common cultural concepts and value disciplines formed by a region in the course of long-term economic development and economic activities; political culture is mainly composed of people's political psychology, political ideology and other elements, which affects people's evaluation and selection of political systems and government policies; spiritual civilization refers to the way of thinking and value concepts that people form in the long-term development. These three complement each other and together constitute the distinctive culture of different regions.

Influence is "the ability of cultural activists to influence the others' behavior in a favorite way' and it is 'a controlling ability" as well, expressed as "the purposeful control from influence senders to influence receivers on their perception, tendency, opinions, attitudes, beliefs and external behaviors." [4] Regional culture is a cultural characteristic that is clearly related to the geographical location formed by people's longterm life practices in different geographical environments and natural conditions. "This kind of regional culture naturally has a variety of impacts on various areas of the region and becomes the invisible force in spiritual support, consensus cohesion, value guidance and behavioral norms in production and living in the region, as well as influences other region during regional cultural interactions"[5]. Meng Zhaoyi, Qu Aixue and Qiu Fangdao used Jiangsu Province as an example to conduct data analysis on the dynamic changes and spatial differentiation of Jiangsu's cultural capital, pointing out that in future Jiangsu should continuously innovate development models. [6] Qiu Aimei took regional culture as the cutpoint and regarded regional culture as a special cultural form, analyzed the general characteristics it possesses and discussed the influence of cultural factors on the establishment of regional brand. [7] Luo Nengsheng, Guo Gengchen and Xie Li believe that cultural influence belongs to a kind of cultural soft power, and it shall also include cultural productivity, cultural communication, cultural support, cultural innovation and the power of core culture. [8]

Regional cultural influence "is an important component of cultural soft power, is the penetration and occupancy of cultural communication, and the ability of the audience has in the psychological, ideological, emotional and behavioral aspects, which consists of the ability to produce and disseminate cultural content and the influence of cultural communication" [9] Hou Yanyan and Li Rongju analyzed the role of new media communication in improving regional cultural soft power and proposed to regard new media as an important platform to enhance regional cultural soft power. [10] Feng Yingjuan divided the regional culture into advanced culture and backward culture, analyzed the constituent elements of regional advanced culture influence, and put forward suggestions on how to enhance the influence of regional advanced culture. [11]

Therefore, regional cultural influence can be seen as the basis of regional culture's achievements and levels of regional civilization. Innovation and opening up have always been the sources of the growing power of regional culture in Hunan Province. As early as 2008, the total output of the cultural industry in Hunan Province has already exceeded the one hundred billion yuan. This is due to its brave heart to innovate and open up to make people of Hunan open and easy to accept new things. In addition, regional cultural influence should also include the support and maintenance of regional culture for the socio-economic development of the region. The strong sense of merchandise and utilitarianism has contributed to Guangdong's brilliant economic development today. Now Guangdong Province has become the country's first economic province, and its economic growth has reached the standard of moderately developed country.

\section{TO DETERMINE REGIONAL CULTURAL INFLUENCE UNDER THE BACKGROUND OF "INTERNET PLUS"}

What kind of regional culture shall be developed? How to develop regional culture? What kind of result does it get? These questions all point to the ultimate question - how to determine regional cultural influence? Under the background of the "Internet Plus" era, how should the size of a region's cultural influence be determined? Judging from the concrete practice of regional cultural communication and development, we mainly use the three indicators of historical accumulation, modern development and mass impressions to determine the cultural influence embodied in a region.

\section{A. Historical Accumulation}

The cultural influence of a region is gradually accumulated and precipitated during the long historical development. Recognize and discover attractive and characteristic cultures, especially carry out comprehensive and systematic excavation and research of cultural resources scattered in the folk sectors and completely classify and sort the categories, forms and characteristics of cultural resources in the region so that the industrialization of regional cultural resources could be 
realized prior to the implementation of "Internet Plus" plan. Such a process can indicate that the historical accumulation of a region has brought about a certain impact on the region.

Firstly, historical documents can be the best witness for they have seen how a region comes here from history. The essence of the historical culture in one a region for a large part of it actually originates from the historical documents that have remained in the region. At present, many regions have attached great importance to the wealth left over from history and have successively carried out the collection and sorting of historical documents. Historical books that could not be found through all the libraries in the past have finally revived in recent years. They have not only provided rich historical data for relevant research workers, but also recreated regional history for people inside and outside the region. The wealth left over from history should be all the historical documents in a region, not just the works of the previous officials or academic masters. Many people believe that if people in the region have had a significant impact on local or national affairs at that time, the works they wrote must be important historical and cultural resources. It is necessary to dig out cultural resources with regional characteristics and sort, collect and republish the works of celebrities in a region. However, it is obviously not enough to truly reflect the influence of a region. Therefore, genealogies, diaries, letters, local chronicles and other folk documents are of the highest importance. They are closer to people's lives and leave a deep impression on people. Some of these documents reflect the content or characteristics of local culture, while others reflect the historical changes in local regions or the operation mechanism and operation details of the society. Their historical values and cultural values are undoubtedly inestimable and can reflect the social and historical process of a regional culture from the perspective of the masses concretely, thus to determine the cultural influence of a region.

Secondly, the material cultural heritage includes natural scenery and historic sites in the region. These are important resources passed down after being tempered by natural wind and frost, and are the most intuitive expression of regional culture and are the key to the development of local tourism culture as well. For example, Suzhou is famous for its gardens, Hangzhou is famous for its ancient towns, and Xinjiang is famous for its prairie... As the process of urbanization accelerates, it is necessary to strengthen the protection of the material cultural heritage and actively compile and integrate the catalogue of material cultural resources that can be developed as scenic spots, and retain historical information on text, photographs, audio and video. Intangible cultural heritage, in addition to the folk literature, music, dance etc. ten categories stipulated by the United Nations and China, has another important and historically valuable category, which is oral history. Oral history is "a kind of academic activity that records personnel of the past and collects historical data through interviews and oral methods"[12]. In the historical development of a region, there are certainly many stories that have not been recorded. However, some people have experienced the history. Their memory in history is a precious asset. The rapid development and changes in society today are constantly eroding their footprints, but historically they are the most distinctive and non-negligible part of local culture.

\section{B. Modern Development}

Determining the cultural influence of a region depends on how the regional culture brings about the region. To some degree, the development level of economy and politics in a region also reflects the influence of culture in this region.

Economically, under the impetus of new technology such as the Internet, the intelligent sharing economic model is emerging gradually. With the continuous deepening of the application of artificial intelligence technologies such as the Internet, big data, cloud computing, etc. people have been liberated from specific space-time environmental constraints such as fixed office space and event scene. The internet economy, the internet of things economy, digital economy and etc. are actually a kind of intelligent economy. This an economic model brought about by the process of developing regional shared culture in the "Internet + " era, meanwhile it has also promoted the spread of other cultures in this region. People can convert mechanical labor into intelligent labor and application services through computer networking, cloud sharing, and artificial intelligence, replace network circulation with product data circulation, and replicate and distribute it through the "Internet +" intelligent sharing system. It can be seen that the establishment of an intelligent economy model in this region will inevitably bring about an increase in regional cultural influence.

Politically, civil identity, self-consciousness, social freedom, and spiritual civilization in a region will all reflect the level of political construction in the region to some degree and constitute a political culture. China's excellent traditional culture of benevolence, people-oriented, integrity, justice, harmony, and seeking for common ground; revolution culture of seeking truth from facts, working hard, being modest and prudent, and serving the people with integrity and honest and non-corrupt; Jinggangshan Spirit, Long March Spirit, Yanan Spirit the spiritual pursuits, spiritual qualities, and spiritual strengths of the rich and era features such as the aerospace spirit constitute advanced culture and cultural values in various regions. On this basis, the huge advantages of the mobile Internet have accelerated its popularity and application on the people's livelihood. It uses a digital approach to connect "people and public services", which not only greatly enhances the overall service level of the region, but also further enhances the political culture of regional wisdom and people's livelihood.

\section{The Impression of the Masses}

The impression of the masses is a yardstick for judging a regional culture on the road of communication and development, affecting the influence of regional cultural from the inside to the outside. For example, when it comes to Shanghai, known as the "Oriental Paris", people first think of their strong economic strength and unique Shanghai culture; when it comes to Chengdu, which enjoys the reputation of "Land of Abundance", people naturally think of places such as Dujiangyan, Wuhou Temple, and Jiansha Site that have been 
bred for more than 2,600 years; when it comes to Hong Kong, which is hailed as the "Pearl of the Orient", people first think of the political culture that combines Chinese wisdom with the advantages of Western social systems, as well as the economic culture known as the third largest financial center in the world... It can be seen that the key to the culture influence of a region is to see what kind of cognition it has formed in the minds of the people and what kind of concrete impression it has.

The purpose of developing regional culture is to make culture better. Thus, from the masses to the masses, this model also applies to the spread and development of regional culture. So as the process of spreading and developing regional culture under the promotion of the "Internet + " program. The purpose of developing regional culture through the Internet is to enable the people to share these cultural achievements and to serve the people through the grassroots level. Whether it is the development and production of precision users' cultural and creative products or the government's establishment of a public service system and e-government evaluation system, these are all based on the interests of the people ultimately. If the practice is successful and it is praised by everyone, then its regional influence will naturally increase. Such as the construction of the Tibetan, Qiang and Yi Cultural Industrial Corridor and the proposed strategy of the Silk Road Economic Belt, they are both they are both excellent examples of promoting cross-regional interaction of cultures and achieving common building and sharing, which has not only promoted new changes in the world economic landscape, but also promoted our country's development of characteristic cultural industries.

\section{CONCLUSION}

Nowadays, in the context of the "Internet +" program which has penetrated into all regions and industries across the country, the prospects for the development of regional culture are expected. Therefore, when the combination of "Internet +" and regional culture has just begun, the government and companies need to constantly pay attention to the frontier areas of cultural science and technology, pay attention to the development trend of domestic and foreign technology, and constantly adapt to and use the new change brought about by the "Internet +" era, timely adjust and publish corresponding policies and continuously improve the regional cultural influence.

\section{REFERENCES}

[1] Sun Bo. "Internet Plus", Financial Reform and Opportunities [J]. Financial View, 2015(8):38. 孙柏.“互联网+”金融变革与机遇 $[\mathrm{J}]$. 金融 博览, 2015（8）: 38

[2] Ning Jiajun. Implementation Background, Connotation and Main Contents of the "Internet Plus" Action Plan [J]. E-Government Affairs, 2015(6):32. 宁家骏.“互联网+”行动计划的实施背景、内涵及主要内 容[J].电子政务, 2015 (6) : 32.

[3] Huang Chuxin, Wang Dan. What does "Internet Plus" Mean? - A Deep Analysis of “Internet Plus" [J]. News and Writing,2015(5):7. 黄楚新、 王丹.“互联网+”意味着什么—对“互联网+”的深层认识 $[\mathrm{J}]$.新闻与 写作，2015（5）：7.
[4] Yu Guoming. Interpretation of Media Influence - Discussion on the Nature of Media Industry [J].Journal of International Communication, 2003 (2): 5. 喻国明.关于传媒影响力的诠释一一对传媒产业本质的 探讨[J].国际新闻界, 2003 (2)：5.

[5] Building Characteristic Regional Culture and Enhancing Ningbo's Cultural Influence [EB/OL]. http://nb.leju.com/news/2016-05$12 / 07546136312413890603568 . s h t m l$. 建设特色区域文化与增强宁波 文化 影 响 力 $[\mathrm{EB} / \mathrm{OL}]$. http://nb.leju.com/news/2016-0512/07546136312413890603568.shtml.

[6] Meng Zhaoyi, Qu Aixue, Qiu Fangdao. The Difference of Regional Cultural Capital in Jiangsu Province and Its Impact on Regional Economic Development[J]. Geographical Sciences, 2012(12):14461448. 孟召宜、渠爱雪、仇方道.江苏区域文化资本差异及其对区域 经济发展的影响 $[\mathrm{J}]$.地理科学, 2012 (12)：1446-1448.

[7] Qiu Aimei. Analysis of the Influence of Regional Culture on Regional Brand Construction [J]. Northern Economy and Trade, 2015(10):89-90. 邱爱梅. 区域文化对区域品牌建设的影响分析 [J]. 北方经贸, 2015(10): 89-90.

[8] Luo Nengsheng, Guo Gengchen, Xie Li. Regional Culture Soft Power Evaluation in China [J]. Economic Geography, 2010(9): 1502-1503. 罗 能生、郭更臣、谢里.我国区域文化软实力评价研究 [J].经济地理, 2010 (9) : 1502-1503.

[9] Chen Zhaoxia. Enhancing regional cultural influence [N]. Ningbo Daily, January 6, 2012, A4. 陈朝霞.提升区域文化影响力[N]. 宁波日报， 2012 年 1 月 6 日 A4 版.

[10] Hou Yanyan, Li Rongju, New Media Diffusion Boosts Regional Culture Soft Power 侯妍妍、李荣菊.新媒体传播助推区域文化软实力的提升 [J].青年记者, 2016 (8) : 106-107.

[11] Feng Yingjuan, Wang Yan. Influence of Regional Advanced Culture and Its Realization Approach [J]. Journal of Industrial Technological Economics, 2009(8):23-25. 冯英娟、王彦. 区域先进文化影响力的构 成及其实现途径[J].工业技术经济，2009（8）：23-25.

[12] Cao Xingsui. Discussion on the Application Value, Work Specification and Interviewing Procedure of Oral History[J]. China Historical Materials of Science and Technology, 2002(4):335. 曹幸穗.口述史的 应用价值、工作规范及采访程序之讨论 [J]. 中国科技史料, 2002 (4) : 335 . 